\title{
Decolorization of Cheddar cheese whey by activated carbon
}

\author{
Yue Zhang, ${ }^{*}$ Rachel Campbell, $†$ MaryAnne Drake, $†$ and Qixin Zhong ${ }^{* 1}$ \\ *Department of Food Science and Technology, University of Tennessee, Knoxville 37996 \\ †Southeast Dairy Foods Research Center, Department of Food, Bioprocessing and Nutrition Sciences, North Carolina State University, \\ Raleigh 27695
}

\begin{abstract}
Colored Cheddar whey is a source for whey protein recovery and is decolorized conventionally by bleaching, which affects whey protein quality. Two activated carbons were studied in the present work as physical means of removing annatto (norbixin) in Cheddar cheese whey. The color and residual norbixin content of Cheddar whey were reduced by a higher level of activated carbon at a higher temperature between 25 and $55^{\circ} \mathrm{C}$ and a longer time. Activated carbon applied at $40 \mathrm{~g} / \mathrm{L}$ for $2 \mathrm{~h}$ at $30^{\circ} \mathrm{C}$ was more effective than bleaching by $500 \mathrm{mg} / \mathrm{L}$ of hydrogen peroxide at $68^{\circ} \mathrm{C}$. The lowered temperature in activated-carbon treatments had less effect on protein structure as investigated for fluorescence spectroscopy and volatile compounds, particularly oxidation products, based on gas chromatography-mass spectrometry. Activated carbon was also reusable, removing more than $50 \%$ norbixin even after 10 times of regeneration, which showed great potential for decolorizing cheese whey.
\end{abstract}

Key words: activated carbon, norbixin (annatto) removal, Cheddar cheese whey, bleaching, volatile analysis

\section{INTRODUCTION}

Cheese whey is a by-product of cheese manufacturing and has been recently used as a major source of producing nutritional and functional whey protein ingredients (Tejayadi and Cheryan, 1995; Sinha et al., 2007). The high demand of whey protein ingredients warrants the use of both colored and uncolored cheese whey. To produce ingredients with light colors from colored Cheddar cheese whey, bleaching agents such as hydrogen peroxide $\left(\mathrm{H}_{2} \mathrm{O}_{2}\right)$ and benzoyl peroxide are used to oxidize the colorant annatto (norbixin) in liquid whey (Croissant et al., 2009). However, decolorization by the oxidation process may affect the flavor and functionality of whey protein ingredients (Croissant et al., 2009; Jervis et

Received November 25, 2014.

Accepted January 7, 2015.

${ }^{1}$ Corresponding author: qzhong@utk.edu al., 2012). Enzymatic bleaching has also been studied, but the cost and, similar to chemical bleaching, oxidation products are possible constraints in the practical application (Kang et al., 2010; Campbell et al., 2012; Campbell and Drake, 2013).

Physical methods such as effective adsorbents may be used to remove norbixin without the oxidation reactions. Granular activated carbon has been recognized as "the best available technology for removing synthetic organic compounds" from drinking-water sources in the 1986 amendments to the United States Safe Drinking Water Act (Magnuson and Speth, 2005). Activated carbon has been widely used in the food, beverage, pharmaceutical, and chemical industries to purify water (Hamdaoui and Naffrechoux, 2007). The feasibility of decolorizing Japanese soy sauce by activated carbon has been recently demonstrated (Miyagi et al., 2013). In our previous study, the adsorption of annatto by activated carbon was evaluated in buffers at various solution conditions, and the results showed the potential of activated carbon in decolorizing cheese whey (Zhang et al., 2013).

In the present study, the first objective was to evaluate the effectiveness of 2 activated-carbon products on decolorizing colored Cheddar cheese whey, with comparison to bleaching by $\mathrm{H}_{2} \mathrm{O}_{2}$. The effectiveness was evaluated for the reduction of both color and residual norbixin content in Cheddar whey. The second objective was to characterize effects of treatments on protein structure and composition using SDS-PAGE, fluorescence spectroscopy, and the proximate compositions and volatile profiles of the lyophilized whey powders. The last objective was to characterize the possibility of regenerating activated carbon for repeated use.

\section{MATERIALS AND METHODS}

\section{Materials}

Activated carbon CA $($ SGL $8 \times 30)$ and $\mathrm{CB}(\mathrm{CAL}$ $12 \times 40$ ) were from Calgon Carbon Corp. (Pittsburgh, PA). Characteristics of these 2 adsorbents have been presented elsewhere (Zhang et al., 2013). The carbon agents were washed several times with distilled water 
and dried in an oven at $150^{\circ} \mathrm{C}$ for $24 \mathrm{~h}$ before use. Cheddar cheese whey was provided by a local dairy farm in Sweetwater, Tennessee. Unless stated otherwise, other chemicals were purchased from either Sigma-Aldrich Corp. (St. Louis, MO) or Fisher Scientific (Pittsburgh, $\mathrm{PA})$.

\section{Decolorization of Cheddar Cheese Whey by Adsorbents}

The adsorbent was applied in $20 \mathrm{~mL}$ of cheese whey in amber vials. After incubation in a C76 shaking water bath (New Brunswick Scientific, Edison, NJ) operating at $25,30,40$, or $55^{\circ} \mathrm{C}$ and $130 \mathrm{rpm}$ for up to 240 min, the mixture was filtered through a shark-skin filter paper into vials that were wrapped with aluminum foil to minimize degradation and stored at $4^{\circ} \mathrm{C}$ before the next measurement. The treatments without adsorbent were similarly conducted and used as controls for comparison.

\section{Bleaching Cheddar Cheese Whey}

Bleaching-agent $\mathrm{H}_{2} \mathrm{O}_{2}$ was used at $500 \mathrm{mg} / \mathrm{L}$, which was the maximum level in a previous study (Listiyani et al., 2012). The cheese whey was preheated to $68^{\circ} \mathrm{C}$, mixed with $\mathrm{H}_{2} \mathrm{O}_{2}$, and incubated for different durations at $68^{\circ} \mathrm{C}$. After cooling to room temperature $\left(21^{\circ} \mathrm{C}\right), 20$ $\mathrm{mg} / \mathrm{L}$ of catalase was added to the whey to remove any residual $\mathrm{H}_{2} \mathrm{O}_{2}$ (Listiyani et al., 2012).

\section{Measurement of Norbixin in Liquid Samples}

A previously developed method (Croissant et al., 2009; Li et al., 2012) was used to extract and quantify norbixin. In a $50-\mathrm{mL}$ centrifuge tube with $6 \mathrm{~mL}$ of liquid whey, $3 \mathrm{~mL}$ of ethanol, $3 \mathrm{~mL}$ of chloroform, and $1 \mathrm{~mL}$ of $1 \%$ acetic acid were added sequentially and vortexed for $30 \mathrm{~s}$ in each step. The sample was centrifuged at $4,564 \times g$ for $20 \mathrm{~min}$ at $4^{\circ} \mathrm{C}$. The bottom (chloroform) layer was collected, and the volume was measured before solid-phase extraction. To perform solid-phase extraction, $1 \mathrm{~mL}$ of the chloroform extract was transferred onto the Strata- $\mathrm{NH}_{2}$ solid-phase extraction column (model $500 \mathrm{mg} / 3 \mathrm{~mL}$, Phenomenex Inc., Torrance, CA) previously conditioned with $7 \mathrm{~mL}$ of $n$-hexane. The column was washed sequentially with $5 \mathrm{~mL}$ of a binary solvent mixture with equal volumes of $n$-hexane and diethyl ether and $1 \mathrm{~mL}$ of acetone to remove the fat and $\beta$-carotene. The elution of norbixin was enabled with $3 \mathrm{~mL}$ of a $7: 3(\mathrm{vol} / \mathrm{vol})$ methanol:glacial acetic acid mixture. The final norbixin extract (eluent) was measured immediately for absorbance at $460 \mathrm{~nm}$ using a UV-vis spectrophotometer (model 201, Thermo Sci- entific, Waltham, MA). A standard curve was created within the concentration range from $62.5 \mu \mathrm{g} / \mathrm{kg}$ to 1 $\mathrm{mg} / \mathrm{kg}$ norbixin. The norbixin standard was a WS28 annatto product containing $2.8 \%$ norbixin (DD Williamson LLC, Port Washington, WI) and was diluted in a methanol-glacial acetic acid (7:3, vol/vol) mixture to obtain the absolute norbixin concentrations in the standard curve. The measured norbixin concentration was used to calculate the norbixin mass extracted from cheese whey by multiplying the volume of eluent. All treatments were analyzed in duplicate.

\section{SDS-PAGE}

Reducing SDS-PAGE was performed to investigate the effects of adsorbent treatment on protein compositions. Whey samples were diluted 5 times in an SDSPAGE sample buffer (GenScript Corp., Piscataway, NJ) and then heated at $95^{\circ} \mathrm{C}$ for 5 min. Ten microliters of the sample was loaded onto a precast 4 to $20 \%$ gradient polyacrylamide gel (Bio-Rad Laboratories, Hercules, CA) for electrophoresis at $150 \mathrm{~V}$. After fixing, the gel was stained with Coomassie brilliant blue G-250. The destained wet gel was scanned, and the composition of the bands was compared by ImageJ software (National Institutes of Health, Bethesda, MD) using the gel-analysis function. Apparent molecular weights were determined by using a kaleidoscope prestained standard (Bio-Rad Laboratories).

\section{Fluorescence Spectroscopy}

The fluorescence spectra were recorded using an RF1501 spectrofluorometer (Shimadzu Corp., Tokyo, Japan). The excitation wavelength was $285 \mathrm{~nm}$. Both the excitation and emission slit widths were set at $10 \mathrm{~nm}$. The emission spectra were recorded between 300 and $450 \mathrm{~nm}$, with the background fluorescence calibrated using distilled water.

\section{Cheese Whey Powder Production}

After treatment by $40 \mathrm{~g} / \mathrm{L}$ adsorbents at room temperature $\left(21^{\circ} \mathrm{C}\right)$ for $2 \mathrm{~h}$ or $500 \mathrm{mg} / \mathrm{L} \mathrm{H}_{2} \mathrm{O}_{2}$ at $68^{\circ} \mathrm{C}$ for 2 $\mathrm{h}$, cheese whey samples were filtered through a $0.45-\mu \mathrm{m}$ Durapore membrane filter (Millipore, Billerica, MA). Following centrifugation at $4,564 \times g$ for $10 \mathrm{~min}$ at $4^{\circ} \mathrm{C}$ to remove the fat and residual carbon agents, the middle transparent portion was collected and freezedried (model 12 EL freeze drier, VirTis Company Inc., Gardiner, NY). The control sample was prepared by filtration and centrifugation of cheese whey directly, followed by freeze-drying. 


\section{Color Measurement}

The color was measured on a MiniScan XE Plus Hunter colorimeter (Reston, VA). For liquid whey, 6 $\mathrm{mL}$ of a sample was used. For whey powder produced as above, $3 \mathrm{~g}$ of a sample was used. All treatments were analyzed in duplicate.

\section{Proximate Analysis}

Contents of TS, fat, lactose, ash, and nitrogen of cheese-whey powder (whey-protein concentrate) were measured in duplicate. The fat content was analyzed using AOAC method 989.05 (Listiyani et al., 2012). The lactose content was determined by a colorimetric method (Barnett and Tawab, 1957). The ash content was determined by drying powder in a muffle furnace at $550^{\circ} \mathrm{C}$ for $12 \mathrm{~h}$ (Bryant and McClements, 2000). The total nitrogen was analyzed by Kjeldahl (ASTMD 3228) method (Barbano and Clark, 1990). The CP content was calculated from the total nitrogen content using a conversion factor of 6.38 (Barbano and Clark, 1990).

\section{Volatile Compound Analysis}

Volatile compounds were extracted and quantified using an established method for dried dairy ingredients (Wright et al., 2009). Five milliliters of $10 \%$ rehydrated cheese-whey powder was added to $20-\mathrm{mL}$ solid-phase microextraction vials in triplicate. Vials were equilibrated for $25 \mathrm{~min}$ at $40^{\circ} \mathrm{C}$ with $4 \mathrm{~s}$ pulsed $250 \mathrm{rpm}$ agitation. A single divinylbenzene/carboxen/polydimethylsiloxane 1-cm fiber was used for all analyses. The solid-phase microextraction fiber was exposed to the samples for $40 \mathrm{~min}$ at a depth of $3.1 \mathrm{~cm}$. The fiber was retracted and inserted at a 5.0-cm depth in the GC inlet for 5 min. The GC-MS instrument was an Agilent 7820 GC with $5975 \mathrm{MSD}$, and the GC separation was conducted with a ZB- $5 \mathrm{~ms}(30 \mathrm{~m} \times 0.25 \mathrm{~mm}$ i.d. $\times 0.25 \mu \mathrm{m})$ column. Sample introduction was accomplished using a CTC Analytics CombiPal Autosampler (CTC Analytics, Zwingen, Switzerland). Single-ion monitoring was applied for selected compounds for higher sensitivity (Wright et al., 2009).

\section{Regeneration of Activated Carbon}

The $5 \mathrm{~g}$ of activated carbon was packed in a glass column with an inner diameter of $4 \mathrm{~cm}$. the column was used to process cheese whey at a level of about $70 \mathrm{~mL}$ of whey per gram of adsorbent. Once the saturation of adsorption by activated carbon (with unnoticeable effluent) was reached, the activated carbon was retrieved from the column, washed with distilled water 3 times, and then bathed at about $60^{\circ} \mathrm{C}$ in $0.1 \mathrm{M} \mathrm{NaOH}$ for $1 \mathrm{~h}$. After incubation, the adsorbents were washed by distilled water 3 times and dried at $105^{\circ} \mathrm{C}$ for $24 \mathrm{~h}$. This regeneration process was repeated 10 times.

\section{Statistical Analysis}

An ANOVA of the data was performed. A least significant difference method at a confidence interval of 95\% was used to compare means (SAS 9.3, SAS Institute Inc., Cary, NC).

\section{RESULTS AND DISCUSSION}

\section{Effectiveness of Decolorization by Activated Carbon and Hydrogen Peroxide}

Visual appearance of samples after treatment by 40 $\mathrm{g} / \mathrm{L}$ of adsorbents at $30^{\circ} \mathrm{C}$ and bleaching at $68^{\circ} \mathrm{C}$ is presented in Figure 1, showing lighter yellowness for the activated-carbon treatments. The $b$ values measured using the Hunter colorimeter are listed in Table 1 to quantitatively compare yellow color intensity. After treatments by activated carbon $\mathrm{CA}$ and $\mathrm{CB}$, cheese whey showed significant reductions of $b$ values, whereas bleaching with $\mathrm{H}_{2} \mathrm{O}_{2}$ at the recommended concentration and temperature only reduced the color slightly (Table $1)$. The reduction in $b$ value by activated carbon in 10 min was greater than $4 \mathrm{~h}$ of treatment by $\mathrm{H}_{2} \mathrm{O}_{2}$. The yellow color is contributed by norbixin, which is the major component in annatto (Zhang and Zhong, 2013). The quantified residual norbixin contents after treatments are presented in Figure 2. For adsorbents, the amount of norbixin removal increased with the increase of incubation time, which is due to adsorption process, as reported previously based on aqueous solutions (Zhang et al., 2013). The bleaching process did not show dependence on incubation time, which agrees with the color measurement (Table 1 ). This is likely because oxidation reaction by $500 \mathrm{mg} / \mathrm{L}$ of $\mathrm{H}_{2} \mathrm{O}_{2}$ is mostly completed in less than 10 min at the studied conditions.

Overall, the adsorbents were more efficient than $\mathrm{H}_{2} \mathrm{O}_{2}$ in decolorizing Cheddar cheese whey. Even though bleaching was done at $68^{\circ} \mathrm{C}$, more than $60 \%$ residual norbixin was in the cheese whey (Figure 2), and the $b$ value decreased only from 16.6 to 12.4 after $4 \mathrm{~h}$ (Table $1)$. Our observation is in agreement with the reported $b$ value after $\mathrm{H}_{2} \mathrm{O}_{2}$ treatment (Listiyani et al., 2012). Despite the incomplete removal, the effectiveness of adsorbents in reducing norbixin content compares favorably with the $\mathrm{H}_{2} \mathrm{O}_{2}$ bleaching process used in the dairy industry. For the 2 activated-carbon products, the $b$ values were not significantly different $(P>0.05)$ after treatment (Table 1), but lower residual norbixin 
Table 1. The Hunter $b$ values of Cheddar cheese whey after treatment by $40 \mathrm{~g} / \mathrm{L}$ of activated carbon $\mathrm{CA}$ and $\mathrm{CB}^{1}$ at $30^{\circ} \mathrm{C}$ or $500 \mathrm{mg} / \mathrm{L}$ of hydrogen peroxide at $68^{\circ} \mathrm{C}$ for 0 to $240 \mathrm{~min}^{2}$

\begin{tabular}{|c|c|c|c|c|c|c|c|c|}
\hline \multirow[b]{2}{*}{ Sample } & \multicolumn{8}{|c|}{ Incubation time (min) } \\
\hline & 0 & 20 & 40 & 60 & 90 & 120 & 180 & 240 \\
\hline $\mathrm{CA}$ & $16.8 \pm 0.1^{\mathrm{a}}$ & $9.5 \pm 0.0^{\mathrm{f}}$ & $7.4 \pm 0.1^{\mathrm{h}}$ & $6.8 \pm 0.2^{\mathrm{h}}$ & $5.4 \pm 0.1^{\mathrm{i}}$ & $5.2 \pm 0.1^{\mathrm{i}}$ & $5.2 \pm 0.1^{\mathrm{ij}}$ & $4.6 \pm 0.5^{\mathrm{j}}$ \\
\hline $\mathrm{CB}$ & $16.8 \pm 0.2^{\mathrm{a}}$ & $9.6 \pm 0.2^{\mathrm{f}}$ & $8.5 \pm 0.3^{\mathrm{g}}$ & $8.0 \pm 0.0^{\mathrm{g}}$ & $6.8 \pm 0.2^{\mathrm{h}}$ & $5.7 \pm 0.3^{\mathrm{i}}$ & $5.4 \pm 0.3^{\mathrm{ij}}$ & $4.9 \pm 0.1^{\mathrm{j}}$ \\
\hline $\mathrm{H}_{2} \mathrm{O}_{2}$ & $16.6 \pm 0.1^{\mathrm{a}}$ & $14.4 \pm 0.3^{\mathrm{b}}$ & $13.9 \pm 0.1^{\mathrm{bc}}$ & $13.6 \pm 0.1^{\mathrm{cd}}$ & $13.3 \pm 0.3^{\mathrm{cd}}$ & $13.2 \pm 0.2^{\mathrm{d}}$ & $12.9 \pm 0.2^{\mathrm{de}}$ & $12.4 \pm 0.2^{\mathrm{e}}$ \\
\hline
\end{tabular}

${ }^{\mathrm{a}-\mathrm{j}}$ Means not sharing a common superscript are significantly different $(P<0.05)$.

${ }^{1}$ Calgon Carbon Corp. (Pittsburgh, PA).

${ }^{2}$ Numbers are mean \pm SD from duplicates.

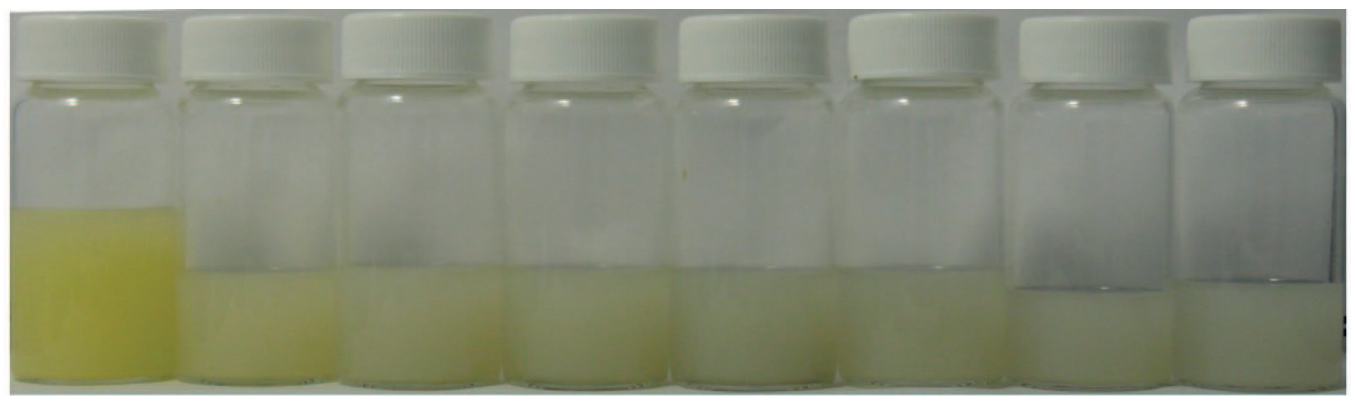

(A)

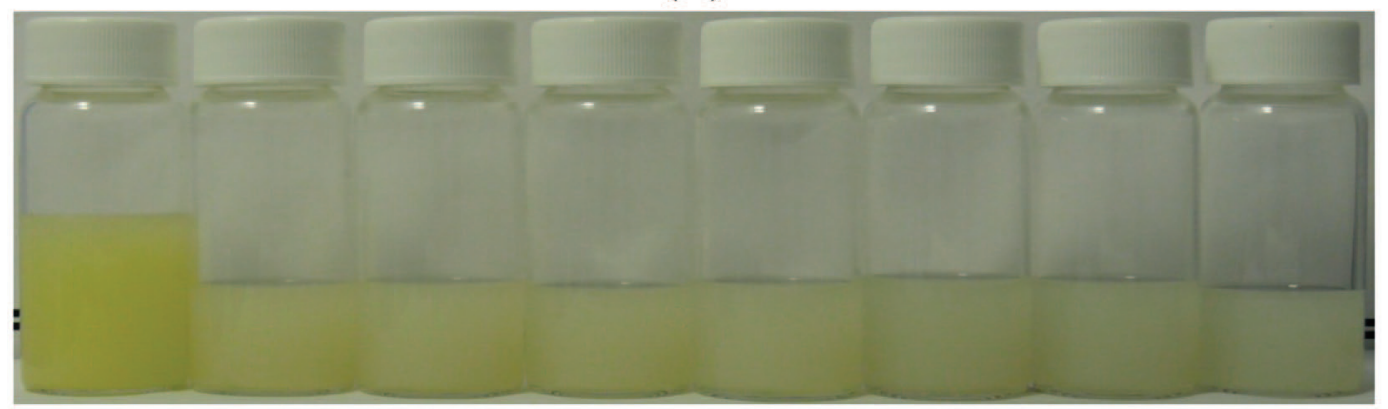

(B)

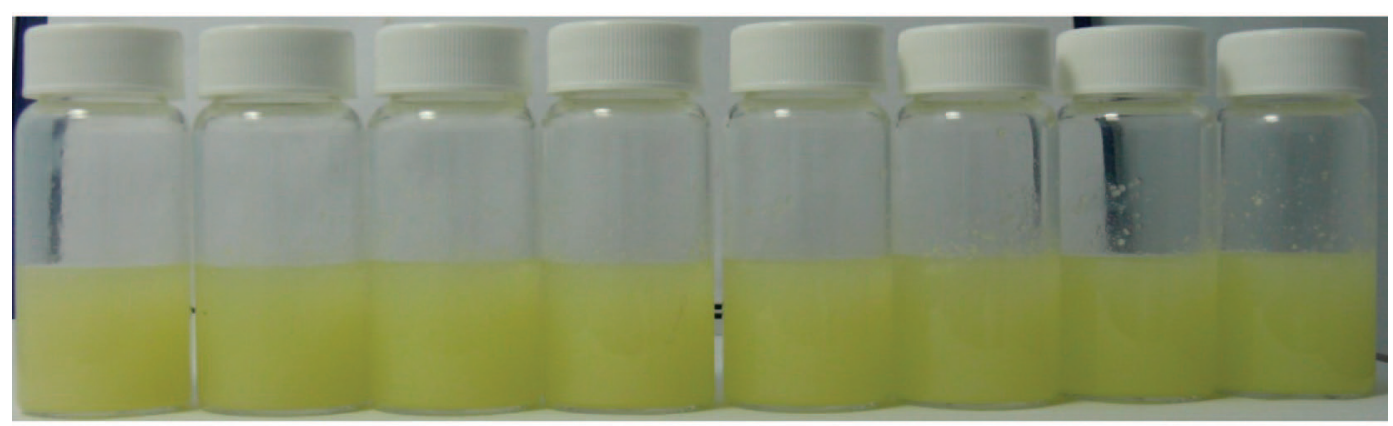

(C)

Figure 1. Appearance of colored Cheddar cheese whey after treatment by $40 \mathrm{~g} / \mathrm{L}$ of activated carbon CA (A) or CB (B; Calgon Carbon Corp., Pittsburgh, PA) at $30^{\circ} \mathrm{C}$ or $500 \mathrm{mg} / \mathrm{L}$ of hydrogen peroxide at $68^{\circ} \mathrm{C}$ (C) for $0,20,40,60,90,120,180$, and $240 \mathrm{~min}$ (vials from left to right). Color version available online. 
Table 2. The Hunter $b$ values of Cheddar cheese whey treated by different levels of activated carbon $\mathrm{CA}$ and $\mathrm{CB}^{1}$ at 3 temperatures for $2 \mathrm{~h}^{2}$

\begin{tabular}{|c|c|c|c|c|c|c|}
\hline Sample & $\begin{array}{c}\text { Temperature } \\
\left({ }^{\circ} \mathrm{C}\right)\end{array}$ & \multicolumn{5}{|c|}{ Concentration of activated carbon $(\mathrm{g} / \mathrm{L})$} \\
\hline \multirow[t]{2}{*}{$\mathrm{CA}$} & 25 & $17.4 \pm 0.1^{\mathrm{a}}$ & $9.4 \pm 0.2^{\mathrm{c}}$ & $8.3 \pm 0.1^{\mathrm{de}}$ & $7.2 \pm 0.3^{\mathrm{f}}$ & $6.1 \pm 0.3^{g}$ \\
\hline & 55 & $17.4 \pm 0.1^{\mathrm{a}}$ & $5.3 \pm 0.1^{\mathrm{h}}$ & $3.3 \pm 0.0^{1}$ & $2.8 \pm 0.1^{\mathrm{m}}$ & $1.2 \pm 0.1^{\circ}$ \\
\hline \multirow[t]{2}{*}{$\mathrm{CB}$} & 25 & $17.4 \pm 0.1^{\mathrm{a}}$ & $8.6 \pm 0.1^{\mathrm{d}}$ & $8.1 \pm 0.2^{\mathrm{e}}$ & $6.9 \pm 0.1^{\mathrm{f}}$ & $6.2 \pm 0.1^{\mathrm{g}}$ \\
\hline & 40 & $16.5 \pm 0.1^{\mathrm{b}}$ & $8.0 \pm 0.1^{\mathrm{e}}$ & $6.2 \pm 0.0^{\mathrm{g}}$ & $4.8 \pm 0.0^{\mathrm{i}}$ & $3.7 \pm 0.1^{\mathrm{k}}$ \\
\hline
\end{tabular}

\footnotetext{
${ }^{\mathrm{a}-\mathrm{o}}$ Means not sharing a common superscript are significantly different $(P<0.05)$.

${ }^{1}$ Calgon Carbon Corp. (Pittsburgh, PA).

${ }^{2}$ Numbers are mean \pm SD from duplicates.
}

concentrations were observed for $\mathrm{CA}$ than $\mathrm{CB}$ at $30^{\circ} \mathrm{C}$. Because the rate of decolorization by activated carbon slowed down after $2 \mathrm{~h}$ (Figure 2), following experiments were performed with an incubation period of $2 \mathrm{~h}$.

\section{Effects of Temperature on Decolorization of Whey by Activated Carbon}

Our previous study recommended that no acidity adjustment of Cheddar cheese whey $(\mathrm{pH}$ 6.4) is required to remove annatto using activated carbon (Zhang et al., 2013). Because temperature is another important factor for adsorption, Hunter $b$ values of the cheese whey treated by different amounts of activated carbon at 25,40 , or $55^{\circ} \mathrm{C}$ were quantified (Table 2 ). The $b$ value of whey was not affected by temperature itself in this range. After treatment by adsorbents, all whey

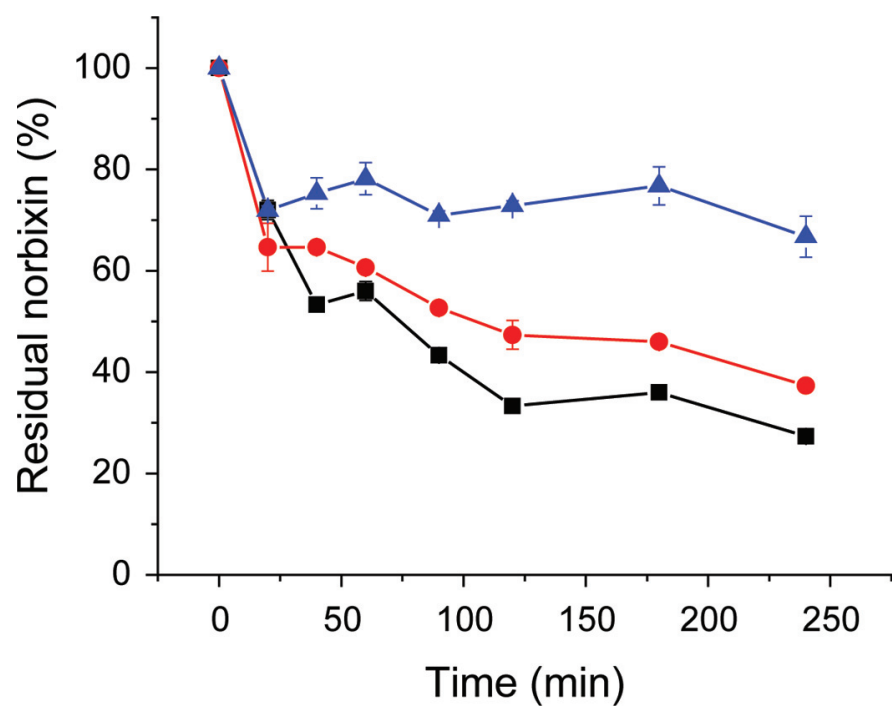

Figure 2. Percentages of residual norbixin after treatment by 40 $\mathrm{g} / \mathrm{L}$ of activated carbon CA (squares) or CB (circles; Calgon Carbon Corp., Pittsburgh, PA) at $30^{\circ} \mathrm{C}$ or $500 \mathrm{mg} / \mathrm{L}$ of hydrogen peroxide (triangles) at $68^{\circ} \mathrm{C}$ for different durations. Error bars are standard deviations from duplicates. Color version available online. samples showed a greater reduction of $b$ values at a higher temperature and a higher adsorbent level (Table $2)$. Overall, no significant difference $(P>0.05)$ was observed for the 2 adsorbents.

Because the color of cheese whey can be contributed to by components besides norbixin, results in Table 2 may not reveal the difference between CA and CB. Therefore, the residual norbixin contents treated by different amounts of activated carbon at 3 temperatures were also quantified (Figure 3). At $25^{\circ} \mathrm{C}, \mathrm{CA}$ was overall more effective than $\mathrm{CB}$ in removing norbixin, which agreed with data at $30^{\circ} \mathrm{C}$ (Figure 2). Previously, we reported the larger surface area of $\mathrm{CB}$ than $\mathrm{CA}$, which resulted in a higher adsorption capacity and better efficiency of $\mathrm{CB}$ in removing norbixin in simple solutions (Zhang et al., 2013). The contradiction of results from simple norbixin solutions and cheese whey likely resulted from the effects of cheese whey components. Small molecules such as lactose in cheese whey can diffuse into micropores or nanopores of activated carbon to reduce the accessibility of internal surface area for adsorption of norbixin and therefore the observed removal efficiency. This hypothesis agrees with the observation that the treatment by $\mathrm{CB}$, with a larger micropore area than CA (Zhang et al., 2013), resulted in a lower lactose content in whey powder than the CA treatment (Table 3 ). At $23^{\circ} \mathrm{C}$, electrostatic attraction was observed to be a major force for the adsorption of norbixin on activated carbon (Zhang et al., 2013). At elevated temperatures such as 40 and $55^{\circ} \mathrm{C}$, other forces such as hydrophobic interactions can also become significant, which results in the improved efficacy of removing norbixin (Figure 3 ) and overall no significant difference between CA and $\mathrm{CB}$ treatments. The exception, the better efficiency of $\mathrm{CB}$ than $\mathrm{CA}$ studied at $55^{\circ} \mathrm{C}$ and $20 \mathrm{~g} / \mathrm{L}$, reflects the larger adsorption capacity of $\mathrm{CB}$ than $\mathrm{CA}$ and the reduced interference of lactose at elevated temperatures. The difference between $\mathrm{CA}$ and $\mathrm{CB}$ treatments at 40 to $80 \mathrm{~g} / \mathrm{L}$ and $55^{\circ} \mathrm{C}$ becomes insignificant when the total surface area of adsorbents is sufficiently large for adsorbing the amount of norbixin in cheese whey. 
(A)

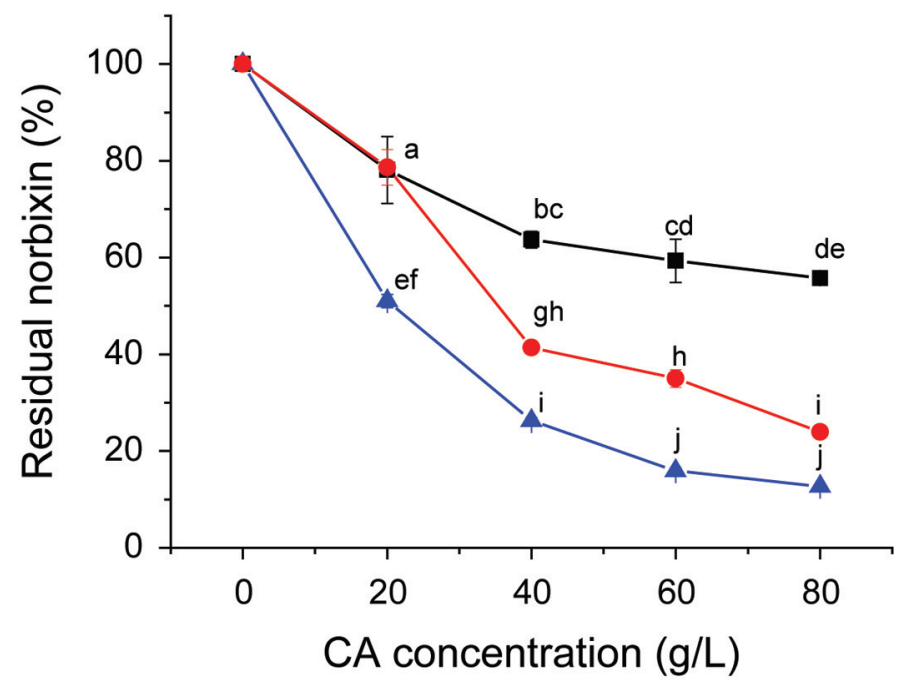

(B)

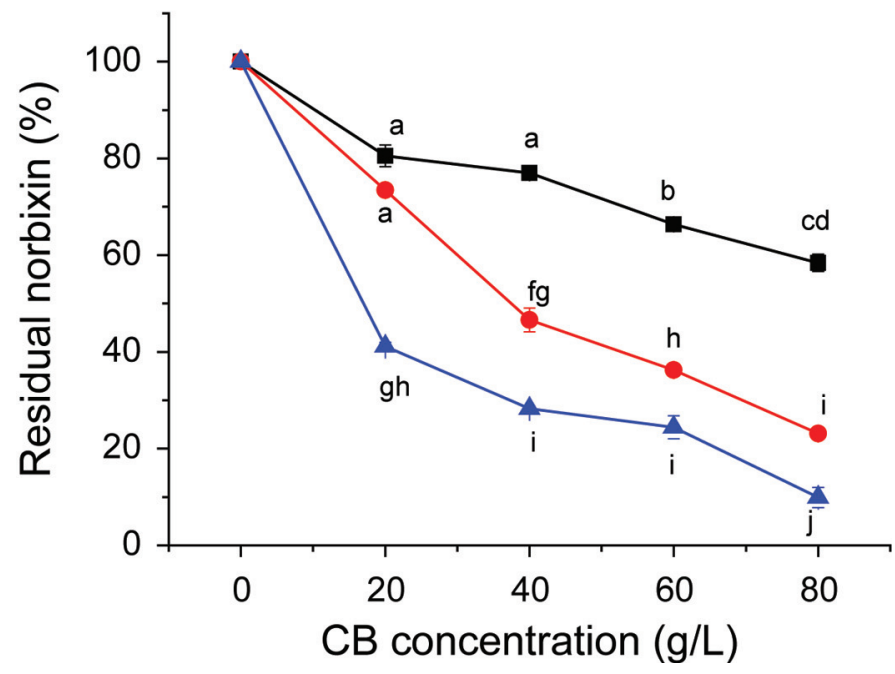

Figure 3. Percentages of residual norbixin after treatment by different concentrations of activated carbon CA (A) or CB (B; Calgon Carbon Corp., Pittsburgh, PA) for $2 \mathrm{~h}$ at 25 (squares), 40 (circles), and $55^{\circ} \mathrm{C}$ (triangles). Error bars are standard deviations from duplicates. ${ }^{a-j}$ Different letters above data points indicate significant difference of the mean $(P<0.05)$. Color version available online.

\section{Effects of Adsorbent Treatment on Protein Composition in Whey}

Effects of adsorption and bleaching on cheese whey protein composition were measured by SDS-PAGE. The 3 major whey proteins $\beta-\mathrm{LG}, \alpha-\mathrm{LA}$, and BSA can be easily identified by SDS-PAGE as 3 major bands at around 18.4, 14.4, and $66.7 \mathrm{kDa}$, respectively (Funtenberger et al., 1997). No obvious changes were observed on the SDS-PAGE profile after bleaching or treatment by activated carbon (Figure 4). The contents of $\beta$-LG
$(18.4 \mathrm{kDa})$ and $\alpha$-LA $(14.2 \mathrm{kDa})$ on the gel were further quantified using image analysis (Figure 5). The band intensity of $\beta-L G$ after all treatments did not significantly decrease (Figure 5A), but the dose of adsorbents had slight effect on $\alpha$-LA (Figure 5B), with the treatment by $40 \mathrm{~g} / \mathrm{L}$ CB being significantly lower than other treatments. The isoelectric point of $\beta-\mathrm{LG}$ and $\alpha-\mathrm{LA}$ is 5.2 and 4.8 to 5.1 , respectively, and the respective zetapotential of $\alpha$-LA and $\beta$-LG at neutral $\mathrm{pH}$ is $-41.6 \mathrm{mV}$ versus $-34.3 \mathrm{mV}$ (Rabiey and Britten, 2009). Because both adsorbents are positively charged (Zhang et al., 2013), the more significant effect of adsorbents on $\alpha$-LA than $\beta$-LG may have resulted from its stronger binding with adsorbents. No significant difference in protein composition after treatment by the 2 adsorbents agrees with their charge characteristics showing similar $\mathrm{pH}$ corresponding to zero net charge $(\mathrm{pH} 10.8$ and 10.3 for CA and CB, respectively, Zhang et al., 2013). Nevertheless, because $\beta$-LG and $\alpha$-LA contribute to more than $90 \%$ of whey proteins (Weinbreck et al., 2003), good retention of the 2 proteins after activated-carbon treatments, especially CA, suggests the potential application of adsorbents to decolorize colored Cheddar cheese whey.

\section{Effects of Treatments on Protein Structure}

Fluorescence technique is a useful method to study the structure of proteins in solution (Eftink, 2006). Because all 3 major whey proteins have tryptophan (Trp) residues that possess intrinsic fluorescence, the changes in protein structure after decolorization can be characterized by fluorescence spectrum (Zhang and Zhong, 2012a). As shown in Figure 6, cheese whey treated by $\mathrm{H}_{2} \mathrm{O}_{2}$ induced the increase of fluorescence intensity and the red shift from 327 to $329 \mathrm{~nm}$, which indicates protein denaturation (Zhang and Zhong, 2012b). In contrast, changes in fluorescence intensity and red shift were much smaller for the adsorbent treatments. The red shift indicates the increased polarity around the major fluorophore Trp, whereas the increased emission intensity suggests the increased exposure of Trp residues (Hu et al., 2009). Therefore, the industrial bleaching process applied at $68^{\circ} \mathrm{C}$ causes denaturation of whey proteins. It has been shown that $\mathrm{H}_{2} \mathrm{O}_{2}$ has a weak ability to hydrolyze whey proteins to peptides and amino acids (Cooney and Morr, 1972). The bleaching temperature $\left(68^{\circ} \mathrm{C}\right)$ is nearby the denaturation temperature of $\beta$-LG $\left(75.9^{\circ} \mathrm{C}\right)$ and above the denaturation temperature of $\alpha-\mathrm{LA}\left(61.0^{\circ} \mathrm{C}\right)$ at $\mathrm{pH} 6.4$ (Bernal and Jelen, 1985). Both factors may have contributed to the denaturation of whey proteins after bleaching. Conversely, adsorbent treatments at room temperature $\left(21^{\circ} \mathrm{C}\right)$ minimized protein denaturation. 
Table 3. Color parameters and proximate analyses of freeze-dried powder prepared from cheese whey without (control) and with treatment by activated carbon $\mathrm{CA}$ and $\mathrm{CB}^{1}$ or hydrogen peroxide ${ }^{2}$

\begin{tabular}{lcrrr}
\hline Item & Control & \multicolumn{1}{c}{$\mathrm{CA}$} & $\mathrm{CB}$ & \multicolumn{1}{c}{$\mathrm{H}_{2} \mathrm{O}_{2}$} \\
\hline Color & & & & \\
$L$ & $93.0 \pm 0.5^{\mathrm{AB}}$ & $93.2 \pm 0.3^{\mathrm{A}}$ & $90.9 \pm 1.0^{\mathrm{B}}$ & $94.2 \pm 0.1^{\mathrm{A}}$ \\
$a$ & $-0.7 \pm 0.3^{\mathrm{B}}$ & $0.4 \pm 0.1^{\mathrm{A}}$ & $0.2 \pm 0.0^{\mathrm{A}}$ & $-2.0 \pm 0.2^{\mathrm{C}}$ \\
$b$ & $20.0 \pm 1.5^{\mathrm{A}}$ & $10.7 \pm 0.9^{\mathrm{B}}$ & $9.7 \pm 0.4^{\mathrm{B}}$ & $18.4 \pm 0.5^{\mathrm{A}}$ \\
TS (\%) & $7.4 \pm 2.0^{\mathrm{A}}$ & $7.2 \pm 1.5^{\mathrm{A}}$ & $7.2 \pm 1.9^{\mathrm{A}}$ & $7.4 \pm 2.0^{\mathrm{A}}$ \\
Lactose (\%) $_{\text {Fat }}^{3}(\mathrm{mg} / \mathrm{L})$ & $52.0 \pm 0.2^{\mathrm{A}}$ & $46.1 \pm 0.1^{\mathrm{C}}$ & $38.0 \pm 0.0^{\mathrm{D}}$ & $49.9 \pm 0.1^{\mathrm{B}}$ \\
Protein (\%) & $0.21 \pm 0.02^{\mathrm{A}}$ & $0.22 \pm 0.02^{\mathrm{A}}$ & $0.23 \pm 0.01^{\mathrm{A}}$ & $0.18 \pm 0.04^{\mathrm{A}}$ \\
Ash (\%) & $12.0 \pm 0.0^{\mathrm{C}}$ & $12.9 \pm 0.1^{\mathrm{B}}$ & $13.5 \pm 0.0^{\mathrm{A}}$ & $12.1 \pm 0.0^{\mathrm{C}}$ \\
\hline
\end{tabular}

\footnotetext{
${ }^{\mathrm{A}-\mathrm{D}}$ Means in the same row not sharing a common superscript are significantly different $(P<0.05)$.

${ }^{1}$ Calgon Carbon Corp. (Pittsburgh, PA).

${ }^{2}$ Activated carbon $\mathrm{CA}$ and $\mathrm{CB}$ were applied at $40 \mathrm{~g} / \mathrm{L}$ of whey at $21^{\circ} \mathrm{C}$ for $2 \mathrm{~h}$, and bleaching was conducted with $500 \mathrm{mg} / \mathrm{L}$ of $\mathrm{H}_{2} \mathrm{O}_{2}$ at $68^{\circ} \mathrm{C}$ for $2 \mathrm{~h}$. Numbers are mean $\pm \mathrm{SD}$ from duplicates.

${ }^{3}$ Fat content was determined by using liquid whey samples before freeze-drying.
}

\section{Proximate Analysis of Cheese Whey Powder}

The color of freeze-dried powders prepared from cheese whey with and without treatments is compared in Table 3. As expected based on Figure 1, adsorbent treatments significantly reduced the $b$ value, whereas bleaching only lowered the $b$ value slightly. Proximate compositions of whey powders before and after treatments are also compared in Table 3. No significant differences in TS content of liquid whey were detected between the adsorbent-treated and bleached samples (7.2 vs. $7.4 \%)$. Similarly, no significant differences $(P$ $>0.05)$ in fat and ash contents were detected among all treatments, suggesting the insignificant adsorption

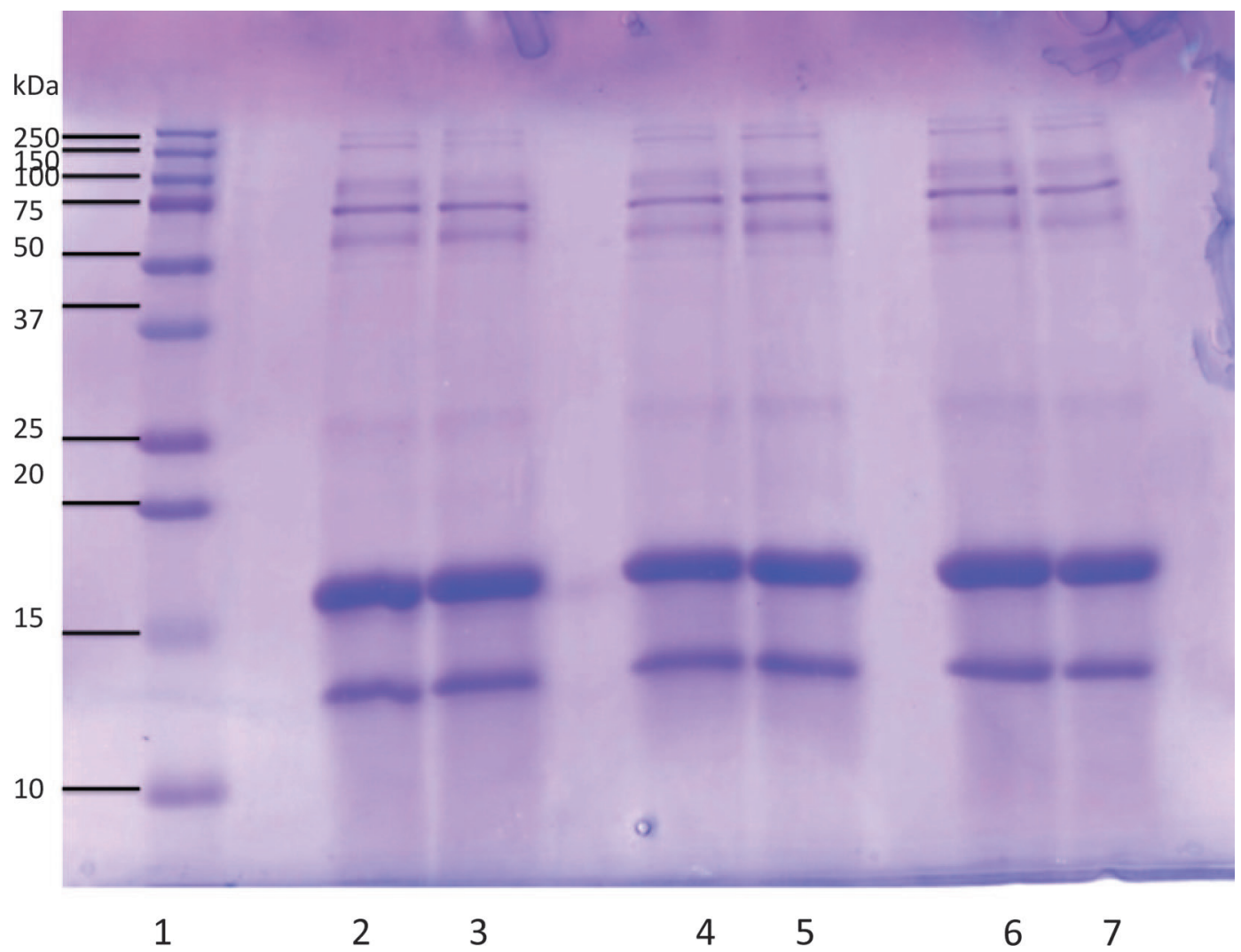

Figure 4. Cheddar cheese whey before (lane 2) and after bleaching by $500 \mathrm{mg} / \mathrm{L}$ of hydrogen peroxide (lane 3 ), treatment by $20 \mathrm{~g} / \mathrm{L}$ of activated carbon CA (lane 4) or CB (lane 5; Calgon Carbon Corp., Pittsburgh, PA), or treatment by $40 \mathrm{~g} / \mathrm{L}$ of activated carbon CA (lane 6 ) or $\mathrm{CB}$ (lane 7 ) for $2 \mathrm{~h}$ at $25^{\circ} \mathrm{C}$. Lane 1 shows protein markers. Color version available online. 
(A)

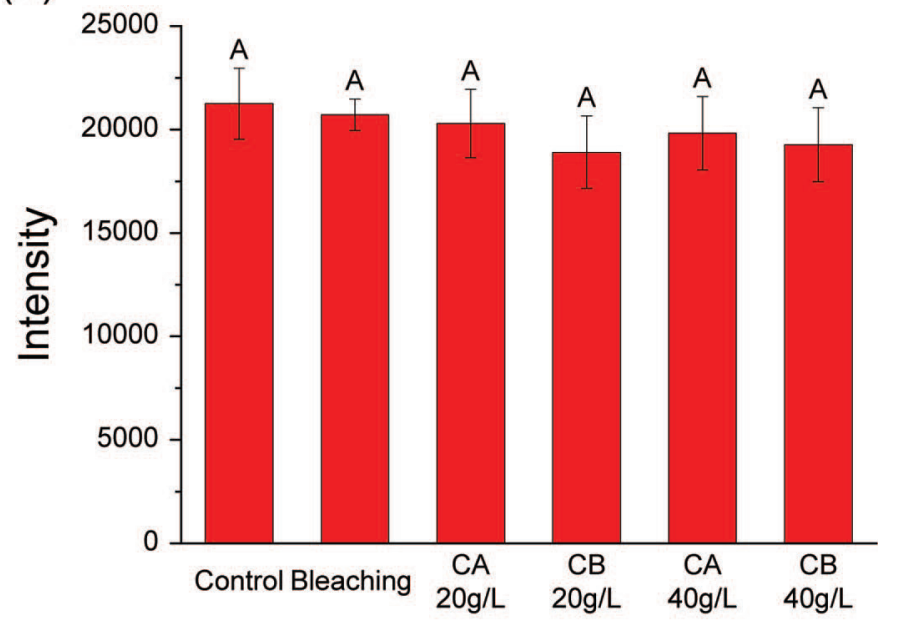

(B)

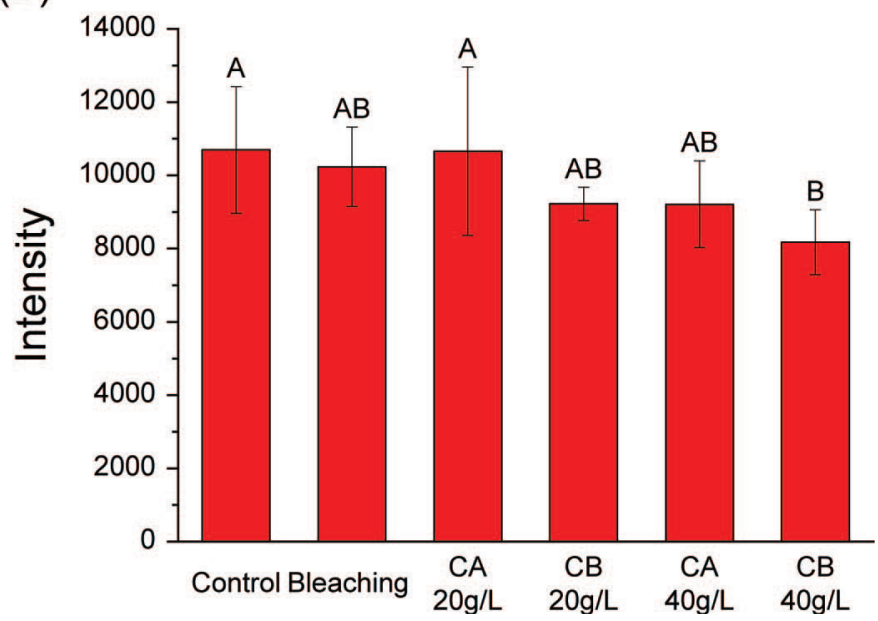

Figure 5. Analysis of SDS-PAGE band intensity of $\beta$-LG (A) and $\alpha-L A(B)$ in cheese whey before and after treatments. Activated carbons $\mathrm{CA}$ and $\mathrm{CB}$ are from Calgon Carbon Corp. (Pittsburgh, PA). Error bars are standard deviations from duplicates. ${ }^{\mathrm{A}, \mathrm{B}}$ Different letters above bars indicate differences in the mean $(P<0.05)$. Color version available online.

of lipid particles and inorganic matter on activated carbon. The increase in protein content of powders from 12.0 to $12.9 \%$ for activated carbon $\mathrm{CA}$ or $13.5 \%$ for $\mathrm{CB}$ treatments can be attributed to the loss of lactose. The loss of lactose may have resulted from the diffusion and entrapment in micropores and nanopores of activated carbon (Zhang et al., 2013).

\section{Volatile Compound Analysis of Cheese Whey Powder}

Different decolorization methods may result in different compositions of cheese whey, especially flavor and volatile compounds (Gallardo-Escamilla et al., $2005 b)$. Several volatile compounds including a range

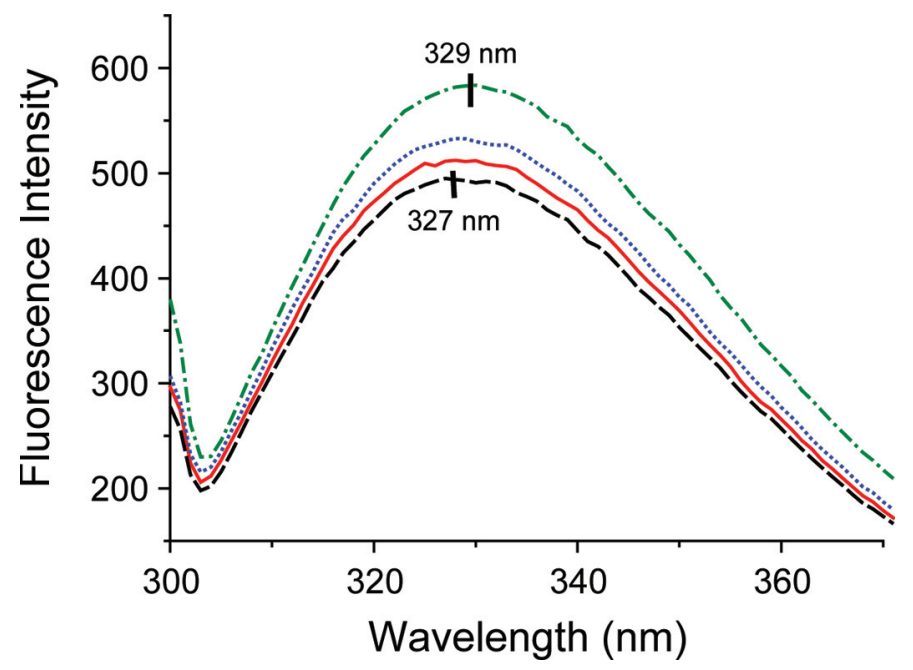

Figure 6. Fluorescence intensity of cheese whey before $(---)$ and after treatment by $40 \mathrm{~g} / \mathrm{L}$ of activated carbon $\mathrm{CA}(-)$ or $\mathrm{CB}(\ldots \ldots$; Calgon Carbon Corp., Pittsburgh, PA) at $25^{\circ} \mathrm{C}$ for $2 \mathrm{~h}$, or $500 \mathrm{mg} / \mathrm{L}$ of hydrogen peroxide at $68^{\circ} \mathrm{C}$ for $2 \mathrm{~h}(-\cdot-)$. Cheese whey was diluted 40 times before fluorescence measurement. Color version available online.

of fermentation flavor compounds as well as Strecker degradation and lipid oxidation products analyzed by solid-phase microextraction GC-MS (Tomaino et al., 2004) are compared in Table 4. Differences between the whey powders with and without treatments were not specifically observed for some volatiles such as 1-hexen3-one, octanal, dimethyl sulfide, and 2,3-octadienone but were evident for others (Kaminarides et al., 2013). For 1-octen-3-ol and dimethyl disulfide, both bleaching and adsorption reduced their contents in whey powder, whereas high amounts of toluene, p-xylene, and decanal were found in the samples after the 2 treatments. The lipid oxidation products such as aldehydes and ketones are the common source of off-flavors in cheese whey. The saturated aldehydes 2-methyl butanal and 3-methyl butanal increased significantly after bleaching, and the increase was less significant after decolorization by activated carbon. The decolorization also decreased the amounts of 2-pentyl furan and diacetyl, but the degree of reduction induced by adsorption was lesser than that by bleaching. The high temperature causes higher concentrations of lipid oxidation products after bleaching (Listiyani et al., 2012). Furthermore, diacetyl is one of the compounds for characteristic sweet, butterscotch aroma and flavor, and the significant loss of diacetyl after hot bleaching is quite undesirable (Gallardo-Escamilla et al., 2005a). In general, decolorization by activated carbon has less influence on the contents of volatile compounds than bleaching but increased amounts of a few compounds such as nonanal when compared with the bleaching treatment. When the 2 activated carbons were compared, CA had smaller effects on most volatile 
Table 4. Select volatile compounds $(\mu \mathrm{g} / \mathrm{L})$ in lyophilized cheese whey powder before (control) and after decolorization by activated carbon $\mathrm{CA}$ and $\mathrm{CB}^{1}$ or hydrogen peroxide ${ }^{2}$

\begin{tabular}{lcccc}
\hline Item & Control & $\mathrm{CA}$ & $\mathrm{CB}$ & $\mathrm{H}_{2} \mathrm{O}_{2}$ \\
\hline 1-Hexen-3-one & $10.0^{\mathrm{B}}$ & $29.4^{\mathrm{A}}$ & $4.40^{\mathrm{B}}$ & $6.09^{\mathrm{B}}$ \\
1-Octen-3-ol & $3.51^{\mathrm{A}}$ & $\mathrm{ND}^{3}$ & $\mathrm{ND}$ & $\mathrm{ND}$ \\
1-Octen-3-one & $0.38^{\mathrm{B}}$ & $2.29^{\mathrm{A}}$ & $0.65^{\mathrm{B}}$ & $1.90^{\mathrm{A}}$ \\
2-Pentyl furan & $100^{\mathrm{A}}$ & $96.1^{\mathrm{A}}$ & $55.5^{\mathrm{B}}$ & $54.8^{\mathrm{B}}$ \\
2,3-Octadienone & $25.2^{\mathrm{A}}$ & $33.0^{\mathrm{A}}$ & $25.7^{\mathrm{A}}$ & $14.2^{\mathrm{A}}$ \\
2-Methyl butanal & $10.1^{\mathrm{C}}$ & $14.5^{\mathrm{B}}$ & $19.4^{\mathrm{A}}$ & $20.4^{\mathrm{A}}$ \\
3-Methyl butanal & $7.93^{\mathrm{B}}$ & $6.78^{\mathrm{C}}$ & $8.33^{\mathrm{B}}$ & $15.0^{\mathrm{A}}$ \\
Decanal & $2.03^{\mathrm{B}}$ & $6.38^{\mathrm{A}}$ & $8.57^{\mathrm{A}}$ & $6.09^{\mathrm{A}}$ \\
Diacetyl & $33.8^{\mathrm{A}}$ & $16.2^{\mathrm{AB}}$ & $25.8^{\mathrm{AB}}$ & $12.2^{\mathrm{B}}$ \\
Dimethyl disulfide & $0.54^{\mathrm{A}}$ & $0.41^{\mathrm{B}}$ & $0.16^{\mathrm{C}}$ & $0.09^{\mathrm{C}}$ \\
Dimethyl sulfide & $0.86^{\mathrm{AB}}$ & $1.00^{\mathrm{AB}}$ & $1.38^{\mathrm{A}}$ & $0.08^{\mathrm{B}}$ \\
Heptanal & $36.4^{\mathrm{C}}$ & $52.9^{\mathrm{A}}$ & $40.3^{\mathrm{BC}}$ & $44.9^{\mathrm{B}}$ \\
Hexanal & $115^{\mathrm{A}}$ & $95.6^{\mathrm{B}}$ & $75.7^{\mathrm{C}}$ & $107^{\mathrm{AB}}$ \\
Nonanal & $0.42^{\mathrm{B}}$ & $26.9^{\mathrm{A}}$ & $29.2^{\mathrm{A}}$ & $1.11^{\mathrm{B}}$ \\
Octanal & $3.28^{\mathrm{AB}}$ & $5.53^{\mathrm{A}}$ & $4.55^{\mathrm{AB}}$ & $1.99^{\mathrm{B}}$ \\
Pentanal & $3.66^{\mathrm{B}}$ & $7.68^{\mathrm{B}}$ & $13.2^{\mathrm{A}}$ & $6.30^{\mathrm{B}}$ \\
p-Xylene & $10.9^{\mathrm{B}}$ & $21.0^{\mathrm{A}}$ & $26.1^{\mathrm{A}}$ & $20.0^{\mathrm{A}}$ \\
Toluene & $11.4^{\mathrm{B}}$ & $32.9^{\mathrm{A}}$ & $40.1^{\mathrm{A}}$ & $44.7^{\mathrm{A}}$ \\
\hline
\end{tabular}

${ }^{\mathrm{A}-\mathrm{C}}$ Means in the same row not sharing a common superscript are different $(P<0.05)$.

${ }^{1}$ Calgon Carbon Corp. (Pittsburgh, PA).

${ }^{2} \mathrm{CA}$ and $\mathrm{CB}$ were applied at $40 \mathrm{~g} / \mathrm{L}$ of whey at $21^{\circ} \mathrm{C}$ for $2 \mathrm{~h}$, and bleaching was conducted with $500 \mathrm{mg} / \mathrm{L}$ of $\mathrm{H}_{2} \mathrm{O}_{2}$ at $68^{\circ} \mathrm{C}$ for $2 \mathrm{~h}$. Results are presented as abundance counts relative to the internal standard $(\mu \mathrm{g} / \mathrm{L})$.

${ }^{3} \mathrm{ND}=$ not detected.

compounds than CB. The instrumental analysis, however, requires confirmation using trained panelists.

\section{Adsorption Capacity of Regenerated Activated Carbon}

Another aspect of developing adsorbent-based decolorization technologies is the reusability of activated

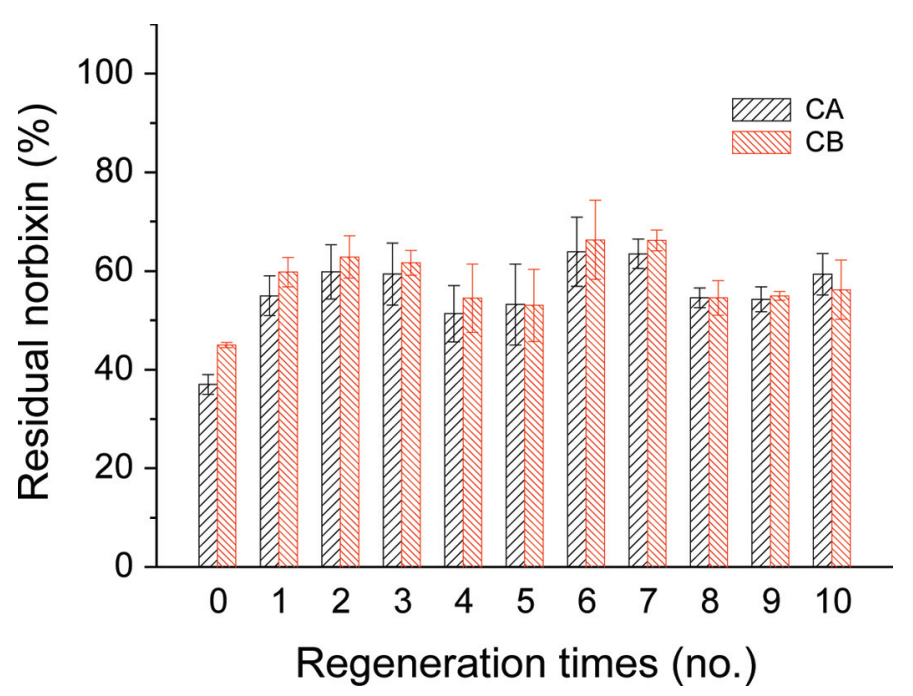

Figure 7. Percentages of residual norbixin after treatment by 40 $\mathrm{g} / \mathrm{L}$ of activated carbon CA or CB (Calgon Carbon Corp., Pittsburgh, $\mathrm{PA}$ ) at $30^{\circ} \mathrm{C}$ for $2 \mathrm{~h}$. CA and $\mathrm{CB}$ were regenerated 10 times for repeated use. Color version available online. carbon. Alkaline hydrolysis has been identified as a useful technology for activated-carbon regeneration after wastewater treatment (Heilmann et al., 1996). In this study, warm $0.1 \mathrm{M} \mathrm{NaOH}$ was used as a reagent for desorption of norbixin and proteins, and the regeneration process was repeated 10 times. As shown in Figure 7 , the remaining norbixin content in cheese whey after treatment by regenerated activated carbon was higher than that treated by fresh activated carbon. But even after 10 times of regeneration, $\mathrm{CA}$ and $\mathrm{CB}$ removed 41.7 and $43.8 \%$ norbixin, respectively, and remained significantly more effective than the bleaching treatment (Figure 2). The 2 adsorbents after regeneration do not differ significantly $(P>0.05)$. The regeneration conditions may be further optimized to improve the norbixin-removal effectiveness of regenerated activated carbon. Nevertheless, the reusability of activated carbon is an important feature to implement the physical method in the dairy industry to decolorize cheese whey. However, detailed cost analyses are needed to consider infrastructures and consumables of applying and regenerating activated carbon.

\section{CONCLUSIONS}

In summary, activated-carbon products were more effective in removing norbixin and reducing the Hunter $b$ value than bleaching using $\mathrm{H}_{2} \mathrm{O}_{2}$. A higher temperature and a higher dose favored the decolorization by activated carbon, and the studied $\mathrm{CA}$ and $\mathrm{CB}$ showed 
no significant difference in their effectiveness of reducing color and norbixin content. Although no significant differences were observed for protein content and composition, more significant protein denaturation was observed after bleaching at $68^{\circ} \mathrm{C}$ than adsorbent treatment at room temperature. The adsorbent treatments had less influence on volatile compounds than bleaching, especially those linked to oxidation. The promise of activated carbon in decolorizing cheese whey was further supported by the reusability of adsorbents that were more effective than bleaching even after 10 times of regeneration.

\section{ACKNOWLEDGMENTS}

This work was sponsored by the University of Tennessee and the Dairy Research Institute (Rosemont, IL). We thank Wan Wang for assisting statistical analysis.

\section{REFERENCES}

Barbano, D., and J. Clark. 1990. Kjeldahl method for determination of total nitrogen content of milk: Collaborative study. J. Assoc. Off. Anal. Chem. 73:849-859.

Barnett, A. J. G., and G. A. Tawab. 1957. A rapid method for the determination of lactose in milk and cheese. J. Sci. Food Agric. 8:437-441.

Bernal, V., and P. Jelen. 1985. Thermal stability of whey proteins-A calorimetric study. J. Dairy Sci. 68:2847-2852.

Bryant, C. M., and D. J. McClements. 2000. Influence of xanthan gum on physical characteristics of heat-denatured whey protein solutions and gels. Food Hydrocoll. 14:383-390.

Campbell, R., and M. Drake. 2013. Cold enzymatic bleaching of fluid whey. J. Dairy Sci. 96:7404-7413.

Campbell, R., E. Kang, E. Bastian, and M. Drake. 2012. The use of lactoperoxidase for the bleaching of fluid whey. J. Dairy Sci. 95:2882-2890

Cooney, C., and C. Morr. 1972. Hydrogen peroxide alteration of whey proteins in whey and concentrated whey systems. J. Dairy Sci. $55: 567-573$.

Croissant, A. E., E. J. Kang, R. E. Campbell, E. Bastian, and M. A. Drake. 2009. The effect of bleaching agent on the flavor of liquid whey and whey protein concentrate. J. Dairy Sci. 92:5917-5927.

Eftink, M. R. (2006). Fluorescence techniques for studying protein structure. Pages 127-205 in Methods of Biochemical Analysis. John Wiley Sons Inc., New York, NY.

Funtenberger, S., E. Dumay, and J. C. Cheftel. 1997. High pressure promotes $\beta$-lactoglobulin aggregation through $\mathrm{SH} / \mathrm{S}-\mathrm{S}$ interchange reactions. J. Agric. Food Chem. 45:912-921.

Gallardo-Escamilla, F. J., A. L. Kelly, and C. M. Delahunty. 2005a. Influence of starter culture on flavor and headspace volatile profiles of fermented whey and whey produced from fermented milk. J. Dairy Sci. 88:3745-3753.

Gallardo-Escamilla, F. J., A. L. Kelly, and C. M. Delahunty. 2005b. Sensory characteristics and related volatile flavor compound profiles of different types of whey. J. Dairy Sci. 88:2689-2699.

Hamdaoui, O., and E. Naffrechoux. 2007. Modeling of adsorption isotherms of phenol and chlorophenols onto granular activated carbon: Part II. Models with more than two parameters. J. Hazard. Mater. 147:401-411.
Heilmann, H. M., U. Wiesmann, and M. K. Stenstrom. 1996. Kinetics of the alkaline hydrolysis of high explosives RDX and HMX in aqueous solution and adsorbed to activated carbon. Environ. Sci. Technol. 30:1485-1492.

Hu, Y.-J., Y. Liu, and X.-H. Xiao. 2009. Investigation of the interaction between berberine and human serum albumin. Biomacromolecules 10:517-521.

Jervis, S., R. Campbell, K. Wojciechowski, E. Foegeding, M. Drake, and D. Barbano. 2012. Effect of bleaching whey on sensory and functional properties of $80 \%$ whey protein concentrate. J. Dairy Sci. 95:2848-2862.

Kaminarides, S., K. Nestoratos, and T. Massouras. 2013. Effect of added milk and cream on the physicochemical, rheological and volatile compounds of Greek whey cheeses. Small Rumin. Res. 113:446-453.

Kang, E. J., R. E. Campbell, E. Bastian, and M. A. Drake. 2010. Invited review: Annatto usage and bleaching in dairy foods. J. Dairy Sci. 93:3891-3901.

Li, X. E., R. E. Campbell, A. J. Fox, P. D. Gerard, and M. Drake. 2012. Influence of storage, heat treatment, and solids composition on the bleaching of whey with hydrogen peroxide. J. Food Sci. 77:C798-C804.

Listiyani, M. A. D., R. E. Campbell, R. E. Miracle, D. M. Barbano, P. D. Gerard, and M. A. Drake. 2012. Effect of temperature and bleaching agent on bleaching of liquid Cheddar whey. J. Dairy Sci. $95: 36-49$

Magnuson, M. L., and T. F. Speth. 2005. Quantitative structureproperty relationships for enhancing predictions of synthetic organic chemical removal from drinking water by granular activated carbon. Environ. Sci. Technol. 39:7706-7711.

Miyagi, A., H. Nabetani, and M. Nakajima. 2013. Decolorization of Japanese soy sauce (shoyu) using adsorption. J. Food Eng. 116:749-757.

Rabiey, L., and M. Britten. 2009. Effect of protein composition on the rheological properties of acid-induced whey protein gels. Food Hydrocoll. 23:973-979.

Sinha, R., C. Radha, J. Prakash, and P. Kaul. 2007. Whey protein hydrolysate: Functional properties, nutritional quality and utilization in beverage formulation. Food Chem. 101:1484-1491.

Tejayadi, S., and M. Cheryan. 1995. Lactic acid from cheese whey permeate. Productivity and economics of a continuous membrane bioreactor. Appl. Microbiol. Biotechnol. 43:242-248.

Tomaino, R. M., L. G. Turner, and D. K. Larick. 2004. The effect of Lactococcus lactis starter cultures on the oxidative stability of liquid whey. J. Dairy Sci. 87:300-307.

Weinbreck, F., R. de Vries, P. Schrooyen, and C. G. de Kruif. 2003. Complex coacervation of whey proteins and gum arabic. Biomacromolecules 4:293-303.

Wright, B. J., S. E. Zevchak, J. M. Wright, and M. A. Drake. 2009. The impact of agglomeration and storage on flavor and flavor stability of whey protein concentrate $80 \%$ and whey protein isolate. J. Food Sci. 74:S17-S29.

Zhang, Y., K. Pan, and Q. Zhong. 2013. Characteristics of activated carbon and carbon nanotubes as adsorbents to remove annatto (norbixin) in cheese whey. J. Agric. Food Chem. 61:9230-9240.

Zhang, Y., and Q. Zhong. 2012a. Binding between bixin and whey protein at $\mathrm{pH} 7.4$ studied by spectroscopy and isothermal titration calorimetry. J. Agric. Food Chem. 60:1880-1886.

Zhang, Y., and Q. Zhong. 2012b. Effects of thermal denaturation on binding between bixin and whey protein. J. Agric. Food Chem. 60:7526-7531.

Zhang, Y., and Q. Zhong. 2013. Probing the binding between norbixin and dairy proteins by spectroscopy methods. Food Chem. 139:611-616. 